\title{
Reply to the comments on Flores and Bazzalo (2004)
}

\author{
Paulo A.C. Flores ${ }^{1,2 *}$ AND Mariel Bazzalo ${ }^{1,3}$
}

\begin{abstract}
The critique by Wedekin et al. (this volume) to our article entitled "Home ranges and movement patterns of the marine tucuxi dolphin, Sotalia fluviatilis, in Baía Norte, southern Brazil" (Flores and Bazzalo, 2004), is welcome but deserves special concern to us, due to some discrepancies and lack of context. In an attempt to properly respond to it, some aspects on the background of our research and its overlap with the conservation of the studied dolphins need to be highlighted, mainly on the creation and the only specific regulatory legislation applied to the Environmental Protection Area of Anhatomirim (EPAA). The critique itself shows shortcomings including contradiction, redundancy, and misinterpretation or misreading of the paper it criticizes. Some of our arguments below have already been widely discussed over different events and documents. Due to the extensive list, we either omit or only briefly mention these whenever necessary, but we are willing to provide them upon request.
\end{abstract}

\section{Home range methods}

Flores and Bazzalo (2004) underscored that the literature on marine tucuxi home range was limited at the time of publication, with not a single paper available for Sotalia guianensis. The authors decided to implement such studies by their own best discretion.

The text and Figure 2 of Flores and Bazzalo (2004) are self-explanatory on the sufficient sample size. Moreover, we plotted observation area curves for each and all identified dolphins, even those not used in the analysis, prior to pooling them as shown in Figure 2. Individually, some dolphins have their curves stabilized before reaching 30 locations. Therefore, it was assumed the shortcut of 30 locations to have a balance of sufficient number of locations and adequate individual sample size, especially given the low number of photo- identified individuals and the small population size. Furthermore, as it was made clear in Flores and Bazzalo (2004) and stressed elsewhere (e.g. Powell, 2000), the two methods of home range estimation used are quite opposite to each other, so their curves would not be expected to behave in the same manner. We used the shortcut commented above and the MCP method to decide upon sample size. It seems to us that all the comments referring to sufficient sample size in the critique to Flores and Bazzalo (2004) are without merit.
The independence between successive observations would be almost impossible to achieve because of the high level of residency and site fidelity of the studied marine tucuxi population on a day, week, seasonal, or in a long-term basis (Flores 1999, 2003; Flores and Bazzalo, 2004; Flores, unpublished data). However, we trust this violation was minimized by considering only the first photographic record of the individuals for any given sighting or day, as done by Owen et al. (2002) with bottlenose dolphins.

Flores and Bazzalo's (2004) pioneer study aimed at producing the first results of home range for marine tucuxi, applying two different estimators, the MCP and kernel, which were found to be not statistically different between both methods. Further, it showed that these home ranges were extremely small and that core areas fell entirely within a protected area (EPAA). However, while part of the home ranges fell outside EPAA, a portion of the protected area did not overlap with the estimated home ranges. Another aim was to pinpoint conservation implication of these findings. Wedekin et al. (this volume) may have misunderstood and therefore misinterpreted many aspects of the study, leading to inconsistencies in their comments.

\section{Marine protected area design}

The comments related to the Brazilian legislation are a matter of concern to us considering the amount of discrepancies in this section.

Flores and Bazzalo (2004) were erroneously quoted as "... the EPA is instrumental in protecting the southernmost population of the species" while rather, they stated that "... is instrumental in fulfilling its main goal of helping to protect the marine tucuxi population". The establishment of a protected area, including its size and design (boundaries and shape) among other things such as its category, would ideally be a combination of sound scientific data, public interest, legislation support and momentum. The latter includes politics and policy opportunities as well as efforts or campaigns by nongovernmental organizations, public authorities and, rarely, the scientific community. However, such ideal combination rarely occurs due to a number of reasons. As briefly mentioned in Flores and Bazzalo (2004), the EPAA was created solely based on three scientific papers available at that time and it was not the authors' intention to provide the scenario in which it was established.

\footnotetext{
${ }^{1}$ Instituto de Pesquisa \& Conservação de Golfinhos, Florianópolis, SC, Brasil

${ }^{2}$ Núcleo de Unidades de Conservação - IBAMA AM, Rod. Min. João Gonçalves de Souza s/n, Distrito Industrial, Manaus, AM, 69075-830 Brasil.

${ }^{3}$ Carrera de Doctorado en Ciencias Biológicas, Universidad de Buenos Aires, Argentina. E-mail: mbazzalo@hotmail.com

* Corresponding author, e-mail: flores.p@terra.com.br and paulo.flores@ibama.gov.br
} 
Still, regarding the size and design of the EPAA, Hoyt (2005) produced an excellent (and updated) handbook of marine protected areas for cetaceans. According to the latter and to the authors' best knowledge, not a single marine protected area in the world covers the full distribution range of a cetacean population (the 'crude distribution' as mentioned by Wedekin et al. this volume). Further, not one encompasses the entire spatial distribution of the totality of activities that originate human impacts on the population targeted for protection, because it it would be impossible to do so. However, these two factors should apply to the EPAA, according to Wedekin et al. (this volume) and the authors's previous papers (Wedekin et al., 2002 Wedekin and Daura-Jorge, 2003). According to the proposed EPAA scenario (Wedekin and Daura-Jorge, 2003), its effective design "should cover the ... distribution of the human activities that originate them". A simple though unrealistic example would be to include the areas of operation of all fishermen, boats and tourists in the design the EPAA, thus encompassing the entire Baía Norte and the Santa Catarina state coastline. The time issue, both at an immediate and short-term basis, is not at all addressed by Wedekin et al. (this volume), including their own previous work. For instance, Wedekin et al. (2002) stated that marine tucuxis spent $87.8 \%$ of their time in the EPAA but only in $29 \%$ of the EPPA total area. However, it must be emphasized that they applied data collected in 2000-02, without using data evenly distributed through seasons, and without verifying statistical significance. In a more comprehensive assessment at both data collection and statistical analysis of this issue, Bazzalo et al. (submitted) have shown that for $59.87 \%$ of their time dolphins used the EPAA. Also, the full range of behavioural activities including probable mating (as previously reported by Flores 1992, 1999) occur within the EPAA (Bazzalo et al. unpublished data).

We need to reemphasize that indeed the percentage of the home ranges as well as the core areas using the kernel estimator are, respectively, moderately to highly inserted within the EPAA and completely within it, as pointed out in Flores and Bazzalo (2004).

Two other mistakes appear in Wedekin et al. (this volume), regarding the accidental entanglement of dolphins in fishing gear and the impacts originating from the intense boat traffic. The critique stated that: "...we do not know where animals are affected by accidental entanglement in fishing gear...". However, from 1993 to 2004 (P.A.C.Flores, unpublished data, but most of the specimens were collected and stored by LAMAq, UFSC), at least 12 stranded dolphins may have died in fishing nets and from other fishery related wounds (e.g. mutilations of fins). One was a female bearing a fetus, which was witnessed drowning in a set net in the middle of the EPAA by one of us (PACF). At least two other specimens were entangled in the
EPAA according to fishermen. Also erroneously, Wedekin et al. (this volume) mentioned that "...the EPA of Anhatomirim is of great importance in the protection of the resident population of marine tucuxi of Norte Bay, especially from the impacts originating from the intense boat traffic". Pereira et al. (in press) clearly showed that $98 \%$ of 290 geographically referenced encounters of boats with dolphins occurred inside the EPAA. Further, $60 \%$ of these 290 encounters $(n=174)$ were situated in the Dolphin Exclusive Zone, established in 1996 in a very small area within the core area of the dolphins. So the comment on this issue in the critique does not proceed.

Claiming that Global Positioning System devices are not used by most artisanal fishermen in the region is unsupported, and certainly unacceptable to justify ignorance by fishermen on their whereabouts in the EPAA and elsewhere in the bay. The marine limits of the EPAA are indeed clearly detected visually because they stand mostly at one nautical mile from the shoreline, a distance easily estimated by fishermen. Of course there is a need to further mark it with appropriate buoys and other types of marks. Moreover, adequate educational measures should be also considered.

Wedekin et al. (this volume) also appear to ignore the scenario in which the EPAA was created, leading to a number of mistakes, as we pointed out above. Two issues that demonstrate this lack of consistency are the limited knowledge on the marine tucuxi population at the time the EPAA was created and the importance of long term studies with cetaceans. In 1991 and 1992, marine tucuxis used the inlet called Enseada dos Currais over $60 \%$ of the approximately $360 \mathrm{~h}$ they were observed (Flores, 1992). The importance of long term longitudinal studies using individual identification to understand the social and ecological complexity of cetaceans has long been demonstrated (e.g. Mann et al., 2000; Wells, 2003). Wedekin et al. (2004) clearly give more importance to their 3-year study than to much longer ones by Flores and colleagues.

These two issues regarding time (today's use and long term distribution) are clearly combined in the observed shift in the distribution pattern (Flores and Bazzalo, unpubl. data). They have shown that since 2000 marine tucuxis have been using more the southern areas of the EPAA, as well as areas south of its limits. Again, the EPAA was created in 1992 (Federal Decree n ${ }^{\circ} 528$ of May 1992) and its design was based on scarce scientific work (Simões-Lopes, 1988; Flores, 1992,), as stated in Flores and Bazzalo (2004). From 1992 up to 2000, this population of marine tucuxi used only the core area of their current distribution, namely an inlet called Enseada dos Currais or 'zone EDC' (Flores, 1999; Flores and Bazzalo, 2004) for up to $60 \%$ in 1991-92 (Flores 1992), then 51\% in 1993 and decreasing to $5.8 \%$ in 2004 (Flores and Bazzalo, 2006). Wilson et al. (2004) found a very similar long-term shift in range in a common bottlenose dolphin population and discussed its impact on protected areas off Scotland. 
Additionally, such misunderstanding applies to comments on surface area used by dolphins within the EPAA. Flores and Bazzalo (2004) mentioned buffer zones as a well-known general strategy in habitat protection without any specific reference to the Brazilian legislation, specifically the National System of Conservation Units (Sistema Nacional de Unidades de Conservação - SNUC, Federal Law \#9985 of year 2000). Such buffer zones would amount to ecological corridors and/or mosaics of protected areas, a tool already present in Brazilian legislation (SNUC and very recently even in a broader, ecosystem approach in the National Plan of Protected Areas - "Plano Nacional de Áreas Protegidas", Federal Decree \#5788 of 2006). A similar approach is applied in landscape management, also in Brazil. Additionally, further boat traffic, fishery and mussel farming restrictions and regulations, and enforcement, as proposed in Flores and Bazzalo (2004) and elsewhere, would be expected to work. These should then encompass, at least partially, today's known distribution range of dolphins, properly combined in the Management Plan of the EPAA, as commented below.

The EPAA is only one legal and conservation instrument to protect marine tucuxis in Baía Norte. Another is the Federal Law which prohibits killing and harassing marine mammals in Brazilian waters (Federal Law \# 7643 of 1987). Later, as succinctly stated in Flores and Bazzalo (2004), a "Dolphin Exclusive Zone" prohibited tourism and leisure boats to enter an approximately $2 \mathrm{~km}^{2}$ sector (Directive 58-N of January 1998), which included the core area of marine tucuxis (Flores and Bazzalo, 2004). However, the ultimate legal instrument to hopefully achieve the adequate protection of the dolphins in the EPAA and its surroundings is the Management Plan (MP), as stated in SNUC. However, due to a number or reasons, the MP of the EPAA has not yet been published. Wedekin et al. (this volume) also failed to address this in the complex scenario of the EPAA design and size, not only in their critique to Flores and Bazzalo (2004) but elsewhere.

These authors propose to redesign the EPAA but this is hard if not impossible to achieve, because it would require a legal instrument of higher level than the Federal Decree which created the EPAA. Vaguely, the critique mentions "management action both inside and outside of the marine protected area", examples of which were clearly presented by Flores and Bazzalo (2004), besides others that are underway as shown here. Therefore. we do not see the point of these arguments.

Considering today's improved, but not definitive, knowledge on the marine tucuxis in Baia Norte, and taking the Precautionary Principle into account, we are convinced that the original EPAA design and size has been largely effective, although a lot of work remains to be done.

\section{Background and ethics}

Finally, Wedekin \& Daura-Jorge (2003) and Wedekin et al. (2002, in press), cited in the critique, do not provide methodological details or are unclear about definitions which impede us from adequately assessing the suitability of their methods and the meaning of their results. Therefore, their critique to Flores and Bazzalo (2004) should be interpreted with caution.

It is our view that the EPAA, mostly through its MP, should focus on the conservation issues of marine tucuxi dolphins, as their protection is one of two objectives of this protected area. Giving the category of this Conservation Unit as in SNUC (2000), it should foster human living and responsible, environmentfriendly development with clear and workable zoning - such as previously achieved by closing off a small area for tourism and leisure boats. This has hopefully been the contribution of our research. Finally, we believe that more energy, time, efforts and funding should be dedicated in a truly collaborative fashion, towards more research and better conservation of marine tucuxis in Baía Norte. It is our hope that this response to the critique to Flores \& Bazzalo (2004) is a contribution to achieve such goals.

\section{Acknowledgements}

Thanks to colleagues outside our own group or lab for helping to discuss the issues presented here. The manuscript was improved with comments from the editors and a referee. Various conservation and scientific institutions have financially supported and believed in our work for over 15 years. We thus are deeply thankful to Conselho Nacional de Desenvolvimento Científico e Tecnológico - CNPq, International Wildlife Coalition - Brazil, Fundação O Boticário de Proteção à Natureza, Whale and Dolphin Conservation Society, Cetacean Society International, Society for Marine Mammalogy, Ideawild, Humane Society International, Ibama and Earthwatch Institute. The first author (PACF) is now at Ibama (Brazilian Insitute of the Environment and Natural Resources), the Federal Environmental Agency, and his opinions do not necessarily reflect or are endorsed by his employee or any of its employers.

\section{References}

Azevedo, A.F., Laílson-Brito Jr., J., CunHA, H.A. And Van SluYs, M. (2004) A note on site fidelity of marine tucuxis (Sotalia fluviatilis) in Guanabara Bay, southeastern Brazil. Journal of Cetacean Research and Management 6: 265-268.

Daura-Jorge, F.G., WedeKIN, L.L. And Simões-Lopes, P.C. (2004) Variação sazonal da intensidade dos deslocamentos do botocinza, Sotalia guianensis (Cetacea: Delphinidae), na Baía Norte da Ilha de Santa Catarina. Biotemas 17: 203-216. 
FLoRes, P.A.C. (1992) Observações sobre comportamento, movimentos e conservação do golfinho ou boto Sotalia fluviatilis (Gervais, 1853) (Mammalia-Cetacea-Delphinidae) na Baía Norte de Santa Catarina, SC, Brasil. B.Sc. Thesis. Universidade Federal de Santa Catarina. Florianópolis, Brazil. 48p.

FLORES, P.A.C. (1999) Preliminary results of a photoidentification study of the marine tucuxi, Sotalia fluviatilis, in Southern Brazil. Marine Mammal Science 15: 840-847.

FLORES, P.A.C. (2003) Ecology of the marine tucuxi dolphin (Sotalia fluviatilis) in southern Brazil. Ph.D. Thesis. Pontifícia Universidade Católica do Rio Grande do Sul. Porto Alegre, RS, Brazil. 141 pp.

Flores, P.A.C. And Bazzalo, M. (2004) Home ranges and movement patterns of the marine tucuxi dolphin, Sotalia fluviatilis, in Baía Norte, southern Brazil. The Latin American Journal of Aquatic Mammals 3: 37-52.

HoYT, E. (2005) Marine protected areas for whales, dolphins, and porpoises: a world handbook for cetacean habitat conservation. Earthscan, United Kingdom.

ManN, J., ConNor, R.C., TYACK, P.L. AND WhiteheAd, H., (Eds) (2000) Cetacean Societies: Field Studies of Dolphins and Whales. University of Chicago Press, Chicago, IL, USA.

Pereira, M.G., Bazzalo, M. and Flores, P.A.C. (in press) Reações comportamentais de Sotalia guianensis (Cetacea: Delphinidae) durante encontros com embarcações na Baía Norte de Santa Catarina. Revista Brasileira de Zoociências.

Powell, R.A. (2000) Animal home ranges and territories and home range estimators. Pages 65-110 in BOITANI, L. AND Fuller, T.K. (Eds) Research Techniques in Animal Ecology: Controversies and Consequences. Columbia University Press,
New York, NY, USA.

SANTOS, M.C. DE O., AcuÑa, L.B. AND Rosso, S. (2001) Insights on site fidelity and calving intervals of the marine tucuxi dolphin (Sotalia fluviatilis) in south-eastern Brazil. Journal of the Marine Biological Association of the United Kingdom 81: 1049-1052.

Wedekin, L.L. And Daura-Jorge, F.G. (2003) A efetividade da APA de Anhatomirim na conservação do boto-cinza, Sotalia guianensis, na Baía Norte, sul do Brasil. Pages 221 - 227 in Anais do II Simpósio de Áreas Protegidas, Pelotas, RS, Brazil.

Wedekin, L.L., Daura-Jorge, F.G. AND SimÕes-Lopes, P.C. (2002) Desenho de unidades de conservação marinhas com cetáceos: estudo do caso do boto-cinza, Sotalia guianensis, na Baía Norte de Santa Catarina, Sul do Brasil. Pages 56-62 in Anais do III Congresso Brasileiro de Unidades de Conservação, 22-26 November, Fortaleza, CE, Brazil.

Wedekin, L.L., Da-Ré, M.A., Daura-Jorge, F.G. and SimõesLOPES, P.C. (2005) The use of a conceptual model to describe the conservation scenario of the estuarine dolphin within the Baía Norte (North Bay), southern Brazil. Natureza \& Conservação 3(1): 162-170.

Wells, R.S. (2003) Dolphin social complexity: lessons from long-term study and life history. Pages 2-56 in DE WALL, F.B.M \& TYACK P.L. (Eds) Animal Social Complexity: Inteligence, Culture, and Individualized Societies. Harvard University Press, Cambridge, MA, USA.

Wilson, B., Reid, R.J., Grellier, K., Thompson, P.M. AND Hammond, P.S. (2004) Considering the temporal when managing the spatial: a population range expansion impacts protected areas-based management for bottlenose dolphins. Animal Conservation 7: 331-338. 